\title{
Shrimoyee Chattopadhyay
}

Beyond Borders: A Review of Jopi Nyman's Displacement, Memory, and Travel in Contemporary Migrant Writing

\author{
Pro\&Contra
}

1 (2018) 97-101. 



\section{Nyman, Jopi. Displacement, Memory, and Travel in Contemporary Migrant Writing. Brill Rodopi, 2017. Viii +251 pages. ISBN 978-90-04-34205-7. Hb. € 90.00.}

In this volume, Jopi Nyman focuses on mobility and migration, and explores various border crossing narratives in which several cultures come into contact with each other. With particular reference to fictional and autobiographical texts, he investigates the ways in which migrants experience displacement and the transformation the whole process of dislocation generates. He argues that narratives which "originate at border crossings cannot be bound by national borders, languages, and literary and critical traditions" (5). His earlier works also dealt with a variety of cultural narratives of border crossing by diasporic and migrant writers in the United Kingdom and the United States. By focusing on diverse historical and contemporary displacements in Europe and the United States, his book challenges the idea that cultural analysis should focus on one particular nation-state or culture.

Jopi Nyman's volume is a result of, as he formulates in the introduction, "several years of research on postcolonial and transcultural literatures" (VII). He claims that new forms of identities acquired during migration are not always voluntary. The migrant subjects do not choose the journey and mobility but often these are forced upon them. Besides providing new identificatory mechanisms, migration often evokes narratives of displacement, dislocation, relocation as well as memories of loss, famine, and death. Nyman's book examines contemporary Anglophone narratives of global migration with particular focus on three major themes: displacement, memory, and travel. He divides his book into three broad sections. The first part deals with the narratives of displaced persons, especially refugees and forced migrants in the writings of Simão Kikamba, Ishmael Beah, and Jamal Mahjoub. Part Two examines the important role that memory plays in autobiographical and fictional narratives of migration by Madhur Jaffrey, Diana AbuJaber, Abdulrazak Gurnah, and Caryl Philips. In the concluding part, Nyman shows how European identities are revised through the encounter with other cultures both historically and in recent times, as explored by the writings of Jamal Mahjoub and Monica Ali.

During migration and travel, attachment to the native land remains important to migrants: as Nyman argues, memory "provides continuity to the individual and the group by linking the past with present" (91). The opening of his work highlights the involuntary character of migration - the experience of the migrants who are forced into migration and displacement in Africa, Europe, and the United States. The occasional successful attempts of migrants to reconstruct a sense of attachment to the host country emphasize that the migrants tend to remain displaced; most of the time they are not fully accepted by their new community. 
The texts, comprising both fictional and non-fictional narratives of forced migration that Nyman discusses in the first section, enable the readers to have a glimpse at refugees' problematic adaptation to their new places. Refugees frequently suffer from trauma and lack of agency. Although he explores different modes of writing, ranging from prose to poetry, the focus on forced migration provides a consistent theoretical framework. Through the autobiographical stories and poems, he examines the ways in which the refugees imagine themselves as they travel to Britain. This theme is portrayed in the Angolan-born South African writer Simão Kikamba's novel, Going Home (2005), which explores the refugee's journey towards his or her dream place in search of safety and security. The short story, "Last Thoughts on the Medusa" (2008) by the black British/European writer, Jamal Mahjoub, and several other contemporary narratives of forced migration, often focus on the subjects' journey towards Europe, underlining the various ways that the migrants adopt, legally or illegally, to cross borders with the hope of achieving security in Europe. These texts redefine European nation-states as "borderscapes" where the national refugees of the migrants are replaced with transnational identities.

Nyman continues his exploration of the role of memory and history in contemporary migrant writing, with specific attention to effect and emotion. With the help of the readings in the three chapters, in the second part of the book, he examines postcolonial narratives, showing how personal or cultural aspects of the past are affected by memories of home and migration. Memory links the past with the present, giving continuity to the individual and the group. Memories not only express mere nostalgic views of the past but also address the violence, trauma, and racism that have resulted in forced migration. The feeling of nostalgia becomes more intense if the individual happens to be a colored immigrant in a predominantly white society. The immigrants are constantly negotiating between the memories of their homeland and the lives in their new community, both in terms of their cultural identity and the necessity to assimilate into a new space.

The third and final part of the reviewed volume highlights the ways in which cultural encounters are generated by migration and mobility. Nyman addresses this enhancement of cultural encounters in contemporary postcolonial narratives. He pays particular attention to the works of the Sudanese British author Jamal Mahjoub, and British Asian novelist Monica Ali. Their texts represent various forms of mobility which bring different parts of the world in contact with each other. This shows that migration can be both local and global, and also suggests that European as well as national and local identities are transformed during migration. Mahjoub, in his early works, foregrounded questions regarding exile and identity. His 2006 novel, The Drift Latitudes, continues to investigate contemporary and historical encounters between Europeans and their Others. However, the book further problematizes issues of history, identity, and belonging. Similarly to 
Mahjoub, who uses the tropes of transnational travel and migration, Monica Ali's second novel, Alentejo Blue (2006), probes into the ways in which contemporary globalization affects the construction of European identities. Her third novel, In the Kitchen (2009), continues to explore the transformation of Britishness. Reading these narratives in the context of the views of cultural theorists like Homi K. Bhaba and Paul Gilroy, Nyman argued for "the urgency to develop a new hybrid form of Britishness" as is required in the era of globalization (157).

Written in simple but articulate language, Nyman's volume is a useful and enjoyable reading for research scholars as well as students of postcolonial and diaspora studies. It is also a necessary guide for enthusiasts who take interest in exploring border-crossing narratives and refugee writings. Though he intertwines multiple themes in each section, such as trauma and memory, among others, he never loses focus on the broader picture of migration, mobility, and cultural encounter. He offers close readings of the texts paying attention to minute details related to displacement, identity, and culture. The book explores both well-known writings by professionals, such as scholars and academics, as well as uncanonized texts by non-professional writers. However, Jopi Nyman does not provide any final conclusion at the end of the book, which suggests that his present volume is part of an ongoing larger research project. Through the readings of the fictional and non-fictional texts, he continues to evaluate both silenced and emerging narratives of cultural encounters.

Shrimoyee Chattopadhyay is a third year PhD student of the British Studies program at the Doctoral School of Literature, University of Debrecen. Her research area is contemporary postcolonial literature and diaspora fiction and film but her interests include gender studies, urban masculinity and food studies and culture. She works with the texts of contemporary diaspora female writers, such as, Jhumpa Lahiri, Monica Ali. Her main focus lies in the interconnectedness of gender and culinary art. 